\title{
How the car became king
}

\author{
Fighting Traffic: The Dawn of the Motor Age \\ in the American City \\ by Peter D. Norton \\ MIT Press: 2008.396 pp. \$35, £22.95
}

Fighting Traffic tells the story of how cars came to dominate our streets and how new roads reshaped our cities, with many parallels to traffic management today. Technology historian Peter Norton's book focuses on the 1920s, when motorists were in the minority. Motor cars, or pleasure cars, were a luxury and not the necessity they have become in many countries. Early motorists fought for the right to use the streets against strong opposition from non-motorists, who called cars 'juggernauts' and 'villains'. Dislike of cars was fuelled by the rise in traffic accidents, which in 1924 claimed more than 20,000 lives in the United States. Marian L. Telford, a safety activist, wrote in the National Safety News of October 1926 that in Chicago, Illinois, "nearly half of children struck down in city streets were on their home block, a fact indicating that unsupervised street play was probably a much bigger risk factor than journeys to schools or stores".

The key question at the time was whose street was it? Were streets places for social interaction, including children's play and commerce, or were they avenues for movement? And what kind of movement was to be allowed there - pedestrian passage or vehicular transport in the form of trams or cars? Norton considers the question as one of social justice.

Another issue emerged from the controversies of the time: efficiency. Congestion in the streets grew because of the chaotic interference of pedestrians with traffic. Free access to the streets, without rules, slowed transportation between business areas, causing adverse economic effects. In line with economists' views at the time, support for 'free market' use of the street was tempered by the realization that the 'invisible hand' of the market was not imposing natural order as it should. Regulation was called for to improve safety and lessen congestion. Engineer Ernest Goodrich, addressing the 1923 US conference on city planning, argued that "street capacity can be increased effectively by regulating traffic".

The concept of traffic regulation is not new. Julius Caesar restricted freight to the night hours to ease daytime congestion and allow pedestrians and other traffic to use the streets in imperial Rome. What was new in the 1920s was the growth of scientific management. This approach was inspired by the

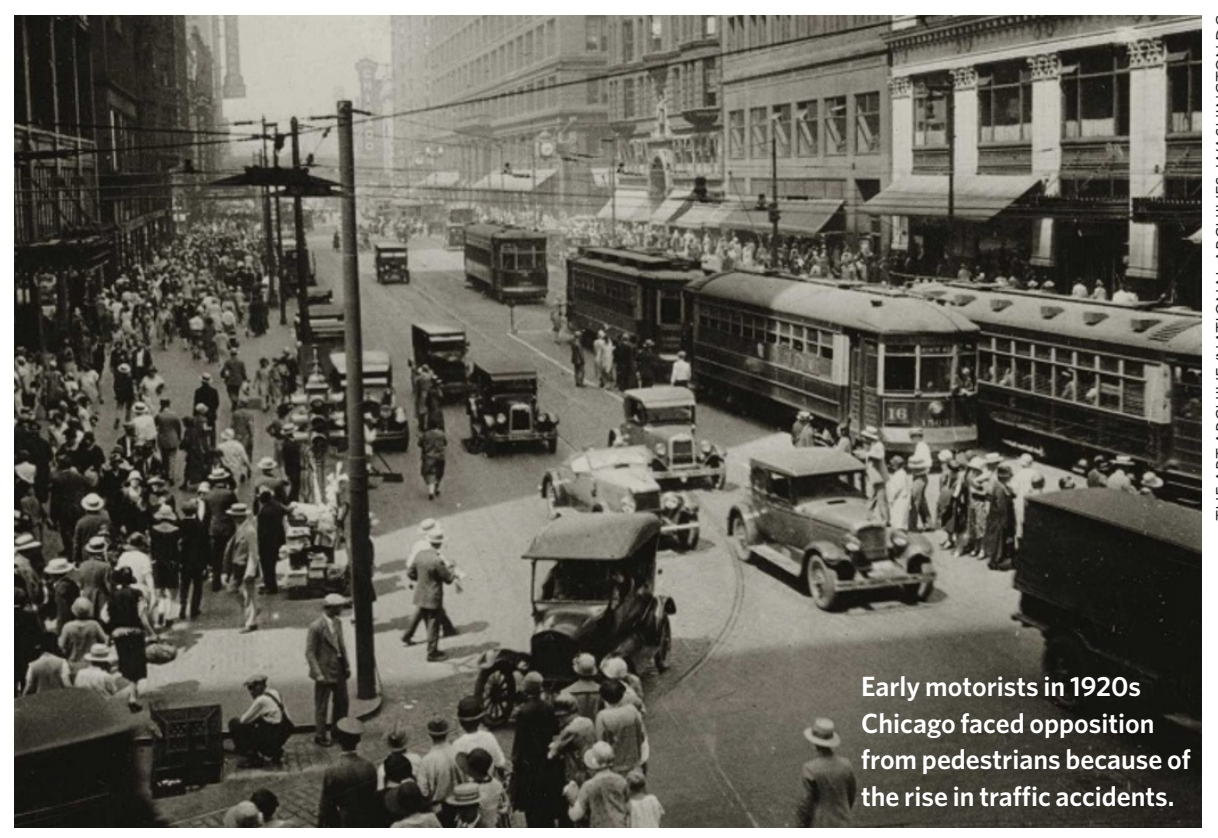

nineteenth-century mechanical engineer Frederick Winslow Taylor, who promoted the idea that systematic analysis was superior to trial-and-error methods. This led to the first traffic survey in Chicago in the 1920s and to the 1924 traffic plan in Los Angeles, California, by landscape architect Frederick Law Olmsted. Regulations introduced progressive measures to separate pedestrian and motor traffic, including signals and parking controls. Today, cities across the world use similar surveys and management schemes.

Regulation also affected non-motorists. Specialized children's playgrounds were introduced, surrounded by fences. Pedestrian movement was controlled by restricting where people could cross streets, along with patrols to help children cross in safety.

By the end of the 1920s, regulation had not cured congestion, and car manufacturers saw the need for more street space to increase car sales. Engineer and future US president Herbert Hoover convened a conference on traffic in 1928, which resulted in an appeal to increase 'floor space' for vehicles. According to Norton, this heralded the triumph of 'motordom' and the reconstruction of the city itself.

A new vision for the city's form was propounded by General Motors at the Futurama show at the World's Fair of 1939-40 in New York. Elevated motorways and high-density skyscrapers dominated the new city design.

The dawn of the motor age in the United States was finally achieved in 1955 by President Dwight D. Eisenhower's national programme of interstate highways. This massive building project provided the freedom of movement that was essential for the economic development of the whole country and improved driving safety. In 1955, it was forecast that the 16 fatalities per 100 million vehicle miles observed in 1938 would be reduced to 5 ; this was achieved by 1966 .

The interstate highway system was probably a major force encouraging the sprawl of US cities. City form always follows the pattern of new transport provision. This was predictable from the shape of Greater London's rapid growth in the late nineteenth century following the introduction of suburban rail networks. As envisaged in the 1940s, internal restructuring of cities also took place, to the great detriment of their historical cores.

It is fascinating to see that the same arguments used in the 1920s to oppose the building of roads are still used. Engineer Arthur S. Tuttle's visionary words in the April 1927 issue of Automotive Industries could have been spoken by today's politicians: new roads "would be filled immediately by traffic which is now repressed because of congestion". The argument that shifting traffic away from city centres "threatens downtown commerce and property values" is also widespread today.

Fighting Traffic traces the main issues around the introduction of the motor car. As the author explains, "The case presented in this book is that before the city could be physically reconstructed for the sake of motorists, its streets had to be socially reconstructed 
as places where motorists unquestionably belonged."

My only reservations about this excellent book are its over-reliance on sociological jargon and that there is not enough discussion of the economic benefits that made the car so successful. In most advanced economies, motor vehicles account for more than $70 \%$ of passenger and freight mobility. The increase in mobility has reduced the monopoly power of city-centre landlords, allowing better and cheaper housing in the suburbs. At the same time, the monopoly power of central business has been reduced by the competition offered by out-of-town retailers. These benefits have improved economic efficiency, but at a considerable environmental cost. Maybe the author should consider writing a sequel about the 'dusk of the motor age' as strong environmental, economic, social and political pressures increasingly threaten motorists' freedom.

Marcial Echenique is professor of land use and transport studies at the Department of Architecture, University of Cambridge, 1-5 Scroope Terrace, Cambridge CB2 1PX, UK. He and Andrew Saint edited Cities for the New Millennium.

\section{In Retrospect: The chromosome trail}

\section{A new translation of Theodor Boveri's 1914 monograph brings the early origins of contemporary cancer research to a wider readership, contends Robert A. Weinberg.}

Concerning the Origin of Malignant
Tumours
by Theodor Boveri. Translated and
annotated by Henry Harris
Cold Spring Harbor Laboratory Press: 2008.
82 pp.

Theodor Boveri (1862-1915) was a towering figure in cell biology and cancer research during the early twentieth century. Trained as a zoologist, he probed the workings of the nucleus and cytoplasm of cells by perturbing them in invertebrate embryos. He was particularly interested in the contributions of chromosomes to cell behaviour. His speculative monograph on the connection between chromosomal anomalies and their role in cancer, published in German in 1914, sealed his scientific reputation.

This monograph, an important source of the origins of contemporary cancer research, has now been translated into English for the second time by Henry Harris, a pioneer in the discovery of tumour-suppressor genes. Boveri's widow and co-worker, Marcella O'Grady Boveri, published the first translation in 1929. Realizing that German biomedical research had begun to lose its dominance worldwide and that German was no longer the sole language of science, she undertook to bring her husband's work to the attention of the non-German-speaking scientific world. Harris's translation presents Boveri's ideas in more contemporary English and is far more accessible. Frequent explanatory footnotes set the arguments in the context of recent findings and, on occasion, in light of twenty-first-century cancer research.

Boveri is remembered for the seminal idea, laid out in Concerning the Origin of Malignant Tumours, that chromosomes are the seats of cell heredity, and that the atypical chromosomes often seen in cancer cells are the basis of these cells' aberrant behaviour. In truth, much of the credit for this prescient suggestion should go to the pathologist David von Hansemann, who, beginning in 1890, published a series of papers on the subject. Von Hansemann noted the tight association between abnormal numbers of chromosomes (aneuploidy) and malignant tissues (neoplasias), but he did not conclude that one invariably causes the other. Boveri notes von Hansemann's contribution in passing and presents evidence for just that conclusion.

To this day, von Hansemann's work remains relatively unknown. He lacked a doting widow to translate his own body of work. And Boveri was a more dominating personality — an otherwise uncritical student described him as a "vehement, inflexible and relentless assailant". Boveri's eclipsing of von Hansemann is reminiscent of how Rudolf Virchow, widely credited with the dictum that all cells arise from the division of pre-existing cells, lifted the idea from the less well-connected Robert Remak, a neurologist who repeatedly reported this finding in the years before Virchow's famous 1858 paper.

Boveri manipulated sea-urchin eggs and embryos. He stripped eggs of their nuclei or fertilized them with multiple sperm. By so doing, he produced evidence for the theory, already in wide circulation, that the determinants of heredity lie in the nucleus, not in the cytoplasm, and that faulty cell division is responsible for the presence of abnormal numbers of chromosomes. From his later experiments, he deduced that each chromosome within a single nucleus must carry a distinct type of heritable information and that proper embryonic development depends on the inheritance of the correct complement of chromosomes.

Boveri seems to have been unaware of the dramatic revolution in genetics that followed the rediscovery in 1900 of Gregor Mendel's all-but-forgotten research into inherited traits. Soon after the rediscovery, several scientists noted the striking parallels between Mendel's genetic determinants and the behaviour of chromosomes - by then known to be present in pairs in ordinary cells, and only singly in sperm and eggs. None of these insights features in the 1914 monograph.

He also studied the two poles that appear at the opposite ends of a cell that is about to divide. These poles anchor and organize the spindle fibres that pull apart two sets of chromosomes during cell division, ensuring each daughter cell receives one complete set. Boveri's focus on the spindles that arise in cells with four poles, rather than the usual two, as the main source of abnormal chromosome numbers now seems simplistic. But it was a good start given the limited experimental tools at his disposal.

What makes Boveri's writing worth reading almost a century later is his ability to distil complex information, including the ideas and observations of others, into brilliant, incisive syntheses. For those biologists among us who are interested in how we got to where we are, this book makes fascinating reading, even if it does not lay down an accurate trail of previous discoveries. Cancer research over the past century has involved a succession of blind alleys and detours, mountains of largely uninterpretable observational data and the occasional brilliant leap forward. This book takes us back to the humble beginnings of this now thriving field.

Robert A. Weinberg is a member of the Whitehead Institute for Biomedical Research and professor of biology, Massachusetts Institute of Technology, 9 Cambridge Center, Cambridge, Massachusetts 02142, USA. He is author of The Biology of Cancer. 